\title{
Evaluation of antibody response to Goat Pox cell culture vaccine in goats in India
}

\author{
S Baksi*, P Puwar, N Rao and R Oza \\ Hester Biosciences Limited, Ahmedabad-380006, Gujarat, India
}

\begin{abstract}
Goat Pox is an important contagious viral disease that causes serious economic loss in small ruminants. The disease causes high morbidity, mortality and trade restriction. Several outbreaks of the disease are reported in Africa and Europe. In India also, the disease has high economic significance. Present study was undertaken to estimate specific antibody response to Live Goat Pox Vaccine in goats. Thirty-five healthy goats were vaccinated with single dose and 10 goats were kept as control. Blood was collected at defined intervals and sera were separated. Virus neutralization test was performed to estimate neutralization index as marker of antibody levels in serum. The study revealed that vaccine could induce immunity against the disease within seven days of vaccination, and reached a peak at 21 days. The titre remained at protective level throughout the oneyear study. Further study can be done to estimate the total duration of immunity through extended study, and the response to challenge with virus. (Bangl. vet. 2016. Vol. 33, No. 1, $23-27)$
\end{abstract}

\section{Introduction}

Goat Pox Disease (GPD) is one of the most significant viral disease infecting small ruminants. The causative agent is Goat Pox Virus, a dsDNA virus in the genus Capripoxvirus, subfamily Chordopoxviridae of Poxviridae family (Van Regenmortel et al., 2000). GPD is highly contagious, affecting goats and sheep and causing huge economic losses (Kamran et al., 2015).

The virus enters via the respiratory tract, and is transmitted through close contact (Kitching, 2004; Radostits et al., 2006). Incubation period is 4-14 days. Within 24 hours of appearance of papules on the body, animals develop rhinitis, conjunctivitis and enlargement of superficial lymph nodes. High mucosal discharge causes difficult and noisy breathing. In acute cases, animals die of respiratory complication and anorexia. Skin lesions due to formation of thrombi persist for up to six weeks, leaving small scars. The acuteness and severity of capripoxvirus infection may vary depending upon the host and strain of virus.

The disease has been reported in North and Central Africa, Middle Eastern countries, Asia and former Soviet Union (Kamran et al., 2015). Recent outbreaks have been reported in Mongolia, Kazakhstan, Azerbaijan, Bulgaria, Greece and Turkey (Beard et al., 2010; Kamran et al., 2015). Several outbreaks of GPD are reported in India,

\footnotetext{
*Corresponding author:- E-mail:drsbaksi.vm@gmail.com
} 
including Karnataka state (Bhanuprakash et al., 2005). Control of GPD is crucial for alleviation of poverty in endemic regions.

Available vaccines for GPD induce immunity after a single injection up to at least the economic life of animals, around three years (Martrenchar et al., 1999; Sreenivasa et al., 2000; Pandey, 2004). Satisfactory serological studies have been performed by many researchers, but the duration of the studies was limited. In the present study, specific antibody response to GPV was studied through an extended period of one year.

\section{Materials and Methods}

\section{Grouping and rearing of goats}

Forty-five healthy Jamunapuri goats of one year of age were divided into two groups:

Group 1: Thirty-five goatswere vaccinated with Live Goat Pox Vaccine (Uttarkashi strain) from Hester Biosciences Limited, India.

Group 2: Ten goats were unvaccinated controls.

Vaccinated goats were kept at Merda-Adraj village, Gujarat, India. Unvaccinated goats were kept at Jetpura village, Gujarat, India. All animals received a free supply of feed and water and were observed daily.

\section{Vaccination, blood collection and testing}

Animals from group 1 were vaccinated subcutaneously in cool atmosphere with one dose of Live Goat Pox Vaccine (Hester Biosciences Limited, Gujarat, India). Blood samples were collected from 10 animals/group from both vaccinated and unvaccinated groups at $0,7,14,21,28,35,42,49$ and 56 days; followed by $3,4,5,6,7$, $8,9,10,11$ and 12 months. At the time of blood collection, no signs of illness were observed. Serum was separated and stored at $-20^{\circ} \mathrm{C}$.

All samples were subjected to Virus Neutralization Test at Hester Biosciences Limited, Anand laboratory (OIE, 2008). Test sera and controls were diluted five times in Eagles/HEPES (N-2-hydroxyethylpiperazine, N-2-ethanesulphonic acid) and inactivated at $56^{\circ} \mathrm{C}$ for 30 minutes. Inactivated $50 \mu \mathrm{L}$ serum was added to columns 1 and 2 in A to $\mathrm{H}$ rows of 96-well flat-bottomed tissue culture grade microtitre plates. Second serum was added in columns 3 and 4 . In columns 5 and 6, third serum was added. Positive and negative controls were added in columns 7 and 8, 9 and 10, respectively. Eagle's/HEPES $(50 \mu \mathrm{L})$ was added in columns 11 and 12, and whole row of H. Goat Pox virus reference strain was diluted in Eagle's/HEPES in a series of log dilutions of $5,4,3.5,3,2.5,2$ and $1.5 \mathrm{TCID}_{50} / \mathrm{mL}$. Log 1.5 dilution virus $(50 \mu \mathrm{L})$ was added in row $\mathrm{G}$ and other dilutions were added each row upwards, till $\log 5$ dilution in row A. The plate was covered and incubated at $37^{\circ} \mathrm{C}$. Cell suspension was prepared in $10^{5}$ cell $/ \mathrm{mL}$ concentration in Eagle's medium with $2 \%$ fetal calf serum. After incubation of plate, $100 \mu \mathrm{L}$ cell suspensions were added to each well, except H11 and 
H12. Again the plate was covered and incubated at $37^{\circ} \mathrm{C}$ for 9 days. Cytopathic effect was observed and recorded for calculation of neutralization index.

\section{Data analysis}

Neutralization index of $\geq 1.5$ was considered as positive. All data were entered into Microsoft Office Excel Worksheet (2013, Microsoft Corporation) and represented as Mean \pm SEM. The data were analyzed by single factor analysis of variance method and $\mathrm{p}<0.05$ was considered as significant difference between the groups.

\section{Results and Discussion}

The initial neutralization index was $0.1 \pm 0.04$ (Group 1) and $0.06 \pm 0.04$ (Group 2). Neutralization index increased gradually in vaccinated goats. At 21 days, it was highest $(2.22 \pm 0.07)$, which was significantly different from 0 days. After 21 days, the index decreased gradually, remaining in the range of $1.82 \pm 0.05$ to $2.11 \pm 0.05$ throughout the year. In unvaccinated goats of group 2, neutralization index was $0.02 \pm$ 0.01 to $0.09 \pm 0.06$ throughout the study (Fig. 1).

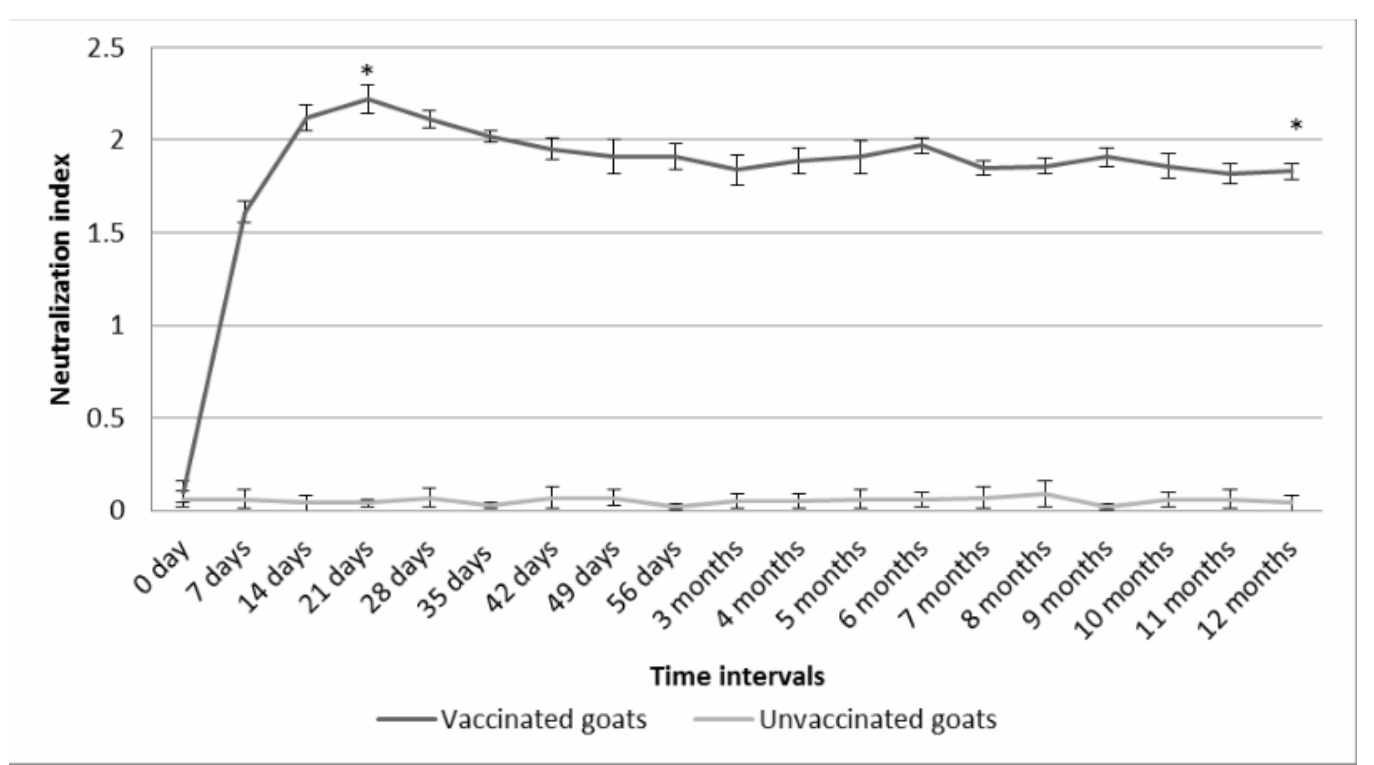

Fig. 1. Neutralization index (Vaccinated and unvaccinated goats)

The data are expressed as mean $\pm \mathrm{SEM} ;{ }^{*} \mathrm{P}<0.05$, significantly different as compared to 0 day

Virus neutralization test was selected to perform serological test as per OIE terrestrial manual, 2008. It is a reliable and accurate method for the measurement of specific antibodies against Goat Pox virus (Sadri et al., 2002; Gelagay et al., 2012). The antibody levels were considered directly proportional to the neutralization index (Zeidan et al., 2016). 
After vaccination, within 7 days only, index value rose rapidly to $1.61 \pm 0.06$ in vaccinated goats, which indicates that vaccine could stimulate the production of specific antibodies to protective level within seven days. Further, the index value rose to maximum after 21 days, i.e., $2.22 \pm 0.07$. Similar observation was reported by Fakri et al. (2015), where neutralization index reached maximum 21 days after vaccination.

Zeidan et al. (2016) performed similar study with optical density as a unit of measurement of specific antibodies: they reported maximum immune response at 10 days. Other researchers performed similar study using virus neutralization test, but the study periods were not more than 28 days (Gelagay et al., 2012). After 21 days of vaccination, the titre remained protective up to one year. Further investigations can be done to understand the protective behaviour of the vaccine extended than one year.

\section{References}

Beard PM, Sugar S, Bazarragchaa E 2010: A description of two outbreaks of capripoxvirus disease in Mongolia. Veterinary Microbiology 142 427-431.

Bhanuprakash V, Moorthy ARS, Krishnappa G, Srinivasa GRN, Indrani BK 2005: An epidemiological study of sheep pox infectionin Karnataka state, India. Revue Scientifique et Technique (International Office of Epizootics) 24 909-920.

Fakri F, Ghzal F, Daouam S, Elarkam A, Douieb L, Tadlaoui K, Fassi-Fihri O, Elharrak M 2015: Field Application of a Combined Vaccine against Peste Des Petits Ruminants and Sheep Pox. Journal of Vaccines and Vaccination 61-4.

Gelagay A, Nigussu F, Shiferaw J, Gedlu M, Teshale S, Haileleul N 2012: Study on immunogenicity of combined sheep and goat pox and peste des petitis ruminants vaccines in small ruminants in Ethiopia. African Journal of Microbiology Research 6 7212-7217.

Kamran M, Seyed MB, Saied B 2015: A review of sheep pox and goat pox: perspective of their control and eradication in Iran Journal of Advanced Veterinary Animal Research 2 373-381.

Kitching RP 2004: Sheep pox and goat pox. In: Infectious Diseases of Livestock, (Coetzer JAW). Capetown: Oxford University Press Southern Africa 2nd Edn. pp. 1277-1281.

Martrenchar A, Zoyem N, Njoya A, Ngo Tama AC, Bouchel D, Diallo A 1999: Field study of a homologous vaccine against Peste des Petits Ruminants in northern Cameroon. Small Ruminant Res. 31 277-280.

OIE Terrestrial Manual 2008: Sheep Pox and Goat Pox, Office International Des Epizooties Paris. Chapter 2.7.14. pp. 1058-1068.

Pandey KD 2004: Sheep pox vaccine production and prospects of eradication of the disease. In: Compendium of Proceedings and Abstracts of the National Symposium on Control of Economically Important Viral Disease of Animal 45. 
Radostits OM, Gay CC, Hinchcliff KW 2006: Veterinary Medicine. Saunders $10^{\text {th }}$ Edn. pp. 1430-1431.

Sadri R, Masoudi S, Kargar R, Khedmati K, Varshovi H, Haghighi S 2002: A Single Radial Haemolysis Technique for Rapid Diagnosis of Goat Pox Diseases. Archives of Razi Institute 54 93-99.

Sathe RG 1931: Pox in sheep. Indian Veterinary Journal 8 118-121.

Sreenivasa BP, Dhar P, Singh RP, Bandyopadhyay SK 2000: Evaluation of an indigenously developed homologous live attenuated cell culture vaccine against peste des petits ruminants infection of small ruminants. In: Proceedings of the XX Annual Conference of Indian Association of Veterinary Microbiologists, Immunologists and Specialists in Infectious Diseases and National Symposium on Trends in Vaccinology for Animal Diseases 84 .

Van Regenmortel MHV, Fauquet CM, Bishop DHL 2000: Virus taxonomy, Classification and Nomenclature of Viruses. $7^{\text {th }}$ Report of the International Committee on Taxonomy of Viruses. Academic Press, San Diego-San Francisco-New York-Boston-LondonSydney-Tokyo.

Zeidan SM, Namaa AM, Hanan MSE, Saad MAA, Olfat EN, Afaf AAW, Abeer AT, ElDakhly AT 2016.Preliminary study for preparation of combined attenuated vaccine against Sheep Pox and PPR viruses. International Journal of Advanced Research 4 212-219. 